\title{
Changing features sighted on the biotechnology horizon
}

Washington

THE landscape of federal support for life sciences has a new feature. A committee on life sciences has formed under the umbrella of the Federal Coordinating Council of Science, Engineering and Technology (FCCSET), to be chaired by Beverly Berger of the White House Office of Science and Technology Policy (OSTP).

Changes in coordination of biotechnology have been expected since the charter for the Biotechnology Sciences Coordinating Committee (BSCC) expired at the beginning of last month. BSCC had no statutory authority but was nevertheless influential. BSCC and its chairman David Kingsbury, associate director of the National Science Foundation (NSF), promulgated the coordinated framework for biotechnology, an attempt to rationalize federal biotechnology regulations.

But BSCC's role and authority became murky this year. As a committee organized under FCCSET, it is subject to authorization from OSTP director William Graham, and there were signals from OSTP that changes were afoot. Complicating matters was the investigation of NSF's Kingsbury for possible conflict of interest charges over his alleged management role in a subsidiary of IGB Products, a British biotechnology holding company, while at NSF.

Under the reorganization, BSCC will continue to function. James Wyngaarden will become chairman, and NSF deputy director John H. Moore will replace
Kingsbury on the committee. BSCC will retain its old functions, and will also liaise with the new FCCSET life sciences committee. The new committee will have a broader membership than BSCC, including representatives from the Office of Management and Budget, the US Trade Representatives Office and most cabinetlevel agencies. Berger has declined to discuss the committee's agenda until its first meeting.

Perhaps the most important role for the new committee will be its oversight of federal activities on the human genome.

Before coming to OSTP, Berger worked for the Department of Energy in the Office of Health and Environmental Research, the office responsible for the Energy Department's human genome activities. There has been some jealousy between federal agencies over who would be leading any federally sponsored mapping effort. The Energy Department and the National Institutes of Health, the two agencies with the largest roles thus far, have recently been working together more congenially, a contrast to some sharpish words spoken earlier in the year.

OSTP's interest in coordinating federal research on the human genome is shared by some in Congress. This week, Senators Kennedy, Chiles and Domenici were expected to introduce legislation that would establish a committee to oversee federal genome activities. The new year may bring even more interested parties.

Joseph Palca

\section{Strawberry plants attacked in Californian field tests}

\section{San Francisco}

IN the latest incident in California's battle between environmental groups and biotechnology, sabotage has delayed a test of genetically engineered frost-preventing bacteria by the Oakland-based company Advanced Genetic Sciences (AGS).

On 30 November, just two days before the test was to begin, vandals slipped past guards, scaled a fence and spread rock salt on the test site, a strawberry field east of San Francisco. The radical environmental group Earth First!, which advocates sabotage, claimed responsibility.

So far, all three California field tests of genetically engineered bacteria - two by AGS and one by the University of California at Berkeley - have been damaged by vandals.

Although the environmental groups have not succeeded in stopping the field tests, they have in some cases reduced their scientific value, and have cost both AGS and the University of California millions of dollars in delays and court battles.

Trevor Suslow, director of product research for AGS, said the rock salt was removed from the field and the plants seem not to be damaged. But, as the vandals claimed to have sprayed a slowacting herbicide as well, AGS will wait a few days before proceeding with the experiment.

The first AGS field test last April was declared a success after no genetically engineered bacteria were found outside the test site and laboratory tests showed the bacteria to confer several degrees of frost protection on the plants. But the vandals had removed many of the blossoms needed for study, and court delays had pushed the test so late into the spring that the plants were not exposed to a

\section{Orphaned embryos to be implanted}

Sydney

AFTER being frozen for six years and in legal limbo for four, two orphaned embryos are to be given a chance to live and breathe.

The embryo's parents, Elsa and Mario Rios, were killed in an aeroplane crash in Chile in April 1983, leaving an \$8 million estate. The Rios came to Australia from California in $\mathbf{1 9 8 0}$ to take part in the in vitro fertilization programme of Melbourne's Queen Victoria Hospital which had no equal in the United States at the time.

Court rulings on both continents were needed to get the embryos out of the deep freeze. In May 1985, a California Superior Court decided not to appoint legal guardians for the embryos and declared that they were not legal heirs to the Rios estate, nor were they its property.

In Victoria, action had to wait for the proclamation of legislation giving the Minister for Health, Mr White, the power to decide the fate of embryos without parents.

The embryos will be implanted in a prospective mother who cannot produce eggs of her own and whose husband cannot produce sperm. Because of the less sophisticated techniques used when they were frozen in November 1981, the chances of either of the embryos surviving the rigours of thawing and implantation are thought to be only 1-2 per cent.

According to White, if the embryo implantation is a success, the children who are born would not be considered relatives of surviving members of the Rios family. He said that the California decision will serve as a precedent in Australia and future orphaned embryos will have to be considered case by case.

In the future, prospective parents depositing prospective children in storage in Victoria will have to sign a declaration setting out what is to become of them should the parents die. Charles Morgan

natural frost. The current test, expected to last for 4 months, should expose the plants to frost in the field.

Suslow said that AGS needs several more field tests before its frost-preventing bacteria will be ready for market. He said the company will not give up Californian field tests, despite the harassment. But as the Organization for Economic Cooperation and Development irons out its regulations for such tests, the company may look abroad for countries more sympathetic to environmental release experiments. Several countries, including Italy, have shown an interest in tempting US biotechnology companies to set up shop outside the United States.

Marcia Barinaga 